\title{
Antibacterial activity of cinnamon (Cinnamomum zeylanicum) essential oil and cinnamaldehyde against fish pathogenic bacteria isolated from cultured olive flounder Paralichthys olivaceus
}

\author{
H. N. K. S. PATHIRANA, S. H. M. P. WIMALASENA, B. C. J. DE SILVA, S. HOSSAIN \\ AND G. J. HEO \\ Laboratory of Aquatic Animal Medicine, Veterinary Medical Center and College of Veterinary Medicine \\ Chungbuk National University, Chungdae-ro 1, Seowon-gu, Cheongju, Chungbuk-28644, Korea \\ e-mail: gjheo@cbu.ac.kr
}

\section{ABSTRACT}

\begin{abstract}
Antibacterial activity of cinnamon (Cinnamomum zeylanicum) essential oil (CEO) and cinnamaldehyde was tested against seven Gram negative and nine Gram positive fish pathogenic bacteria isolated from cultured olive flounder (Paralichthys olivaceus) in Korea. Disk diffusion assay, MIC (minimum inhibitory concentration) and MBC (minimum bactericidal concentration) tests were done. Cinnamon and cinnamaldehyde inhibited the growth of both Gram negative and Gram positive bacteria. Cinnamaldehyde showed lower MIC values than CEO which ranged from 0.001 to $0.015 \%$ (V/V). CEO (MBC/MIC 2-4) was bactericidal for all tested strains while cinnamaldehyde was bactericidal for all except 6 strains. For all fish pathogenic bacteria, the inhibition zone diameter (IZD) increased in proportion to the oil concentration and the maximum effect was found at $100 \%(\mathrm{~V} / \mathrm{V})$ concentration of CEO and cinnamaldehyde. The antibiogram pattern indicated that all the bacterial strains excluding three strains of Streptococcus iniae (S186, S530 and S131) showed resistance to one or more antibiotics. Higher percentages of relative inhibition zone diameter (RIZD \%) were exhibited at higher concentrations of CEO and cinnamaldehyde. Since antibacterial activities of CEO and cinnamaldehyde were considerably effective against fish pathogenic bacteria, these could be used as alternatives to treat bacterial infections in aquaculture.
\end{abstract}

Keywords: Antibacterial activity, Cinnamon essential oil, Cinnamaldehyde, Fish pathogenic bacteria, Olive flounder

\section{Introduction}

In aquaculture industry, diseases of microbial origin are responsible for elevated mortality rates and decreased fish production with consequent economic losses worldwide. The crucial bacterial diseases of marine fish in Korea are Edwardsiellosis caused by Edwardsiella tarda; streptococcosis caused by Streptococcus iniae, S. parauberis and Lactococcus garvieae; and vibriosis caused by Vibrio harveyi, $V$. ichthyoenteri and Photobacterium damselae, which have recently increased in cultured fish populations (Jee et al., 2014; Kim et al., 2015). They have been identified as the etiological agents responsible for the most common disease outbreaks of olive flounder (Paralichthys olivaceus) farms in Korea (Nho et al., 2009).

Antibiotics are widely used to control bacterial infections in fish. However, misuse of antibiotics leads to drug resistance and thereby to their reduced efficacy (Wei and Wee, 2013). Therefore, it is essential to develop alternative drugs using natural substances. Natural products especially from plants have been investigated for their therapeutic and prophylactic effects on several fish diseases (Pongsak and Parichat, 2009; Turker and Yildirim, 2015; Valladao et al., 2015). Essential oils (EOs) are one kind of plant secondary metabolites which have been well known for their aromatic flavour as well as bactericidal, preservative and medicinal properties (Burt, 2004).

Cinnamon (Cinnamomum zeylanicum) is one of the most influential antimicrobial medicinal herbs belonging to Lauraceae family (Prabuseenivasan et al., 2006). It is a tropical evergreen tree which originated from Sri Lanka and being cultivated in Sri Lanka, Madagascar and India. Cinnamon essential oil (CEO) has been applied in food, seasonings, cosmetics and medical industries because of its aromatic, antimicrobial, antioxidant and anti-carcinogenic activities (Yuce et al., 2012; Zouheyr et al., 2014; Raeisi et al., 2015). Cinnamaldehyde is the major component of $\mathrm{CEO}$ and it has at least three mechanisms of action against bacteria depending on the concentrations. At low concentrations, it inhibits enzymes involved in cytokine interactions and other less important cell functions, and it acts as an ATPase inhibitor at high concentrations. At 
the lethal concentration, cinnamaldehyde perturbs the cell membrane (Nazzaro et al., 2013).

Fish diets supplemented with CEO reduced mortality rate of tilapia (Oreochromis niloticus) experimentally infected with $S$. iniae and had no adverse effects on fish (Rattanachaikunsopon and Phumkhachorn, 2010). Antibacterial effect of cinnamon bark extract was reported against fish pathogenic bacteria (S. iniae, E. tarda and Listonella anguillarum) in Korea (Mok et al., 2001). However, no study has been conducted to investigate the antimicrobial properties of CEO and its major components against fish pathogenic bacteria of olive flounders. Therefore, this study was carried out to examine the potential of CEO as well as its main component cinnamaldehyde, which could be utilised in aquaculture as alternatives to commercial antibiotics.

\section{Materials and methods}

\section{Isolation of bacteria}

Seven Gram negative and nine Gram positive bacterial strains isolated from Korean cultured olive flounder were used. The Gram negative strains were E. tarda (ED47, ED45, Yoshida and FP5060), P. damselae (FP4101), V. harveyi (FP 8370), V. ichthyoenteri (FP 4004) and the Gram positive strains were L. garvieae (FP5245), S. iniae (S131, S186, S530 and FP3287) and S. parauberis (S124, S527, S1466 and FP5228). They were obtained from Geyongsang National University, Jinju, Korea and National Institute of Fisheries Science, Busan, Korea.

\section{Essential oil}

Cinnamon essential oil (CEO, Aromarant Co. Ltd., Rottingen, Germany) purified (100\%) from the bark of C. zeylanicum grown in Madagascar and the commercial trans-cinnamaldehyde ( $>99 \%$ ) (Sigma-Aldrich, St. Louis, MO, USA) were purchased.

\section{Disk diffusion assay}

Antibacterial activity of CEO and cinnamaldehyde was evaluated by disk diffusion assay. Sterile paper disks (Advantec Toyo Kaisha Ltd., Japan) were saturated with $20 \mu \mathrm{l}$ of $\mathrm{CEO}$ and cinnamaldehyde at concentrations of $1,5,10,25,50$ and $100 \%(\mathrm{~V} / \mathrm{V})$ and each disk was placed on Mueller Hinton agar (MB Cell, LA, CA) plate smeared with the test strain. Plates were incubated for $24 \mathrm{~h}$ at $27^{\circ} \mathrm{C}$ (Hammer et al., 1999). Antibacterial activity was determined by measuring the inhibition zone diameter (IZD) (mm) against each test strain and expressed as the percentage of relative inhibition zone diameter (RIZD \%) calculated according to a previous study using amoxicillin as a standard antibiotic (Njau et al., 2014).
Determination of the minimum inhibitory concentration (MIC) and minimum bactericidal concentration (MBC)

Determination of MIC was done using broth micro dilution method with some modifications where 5\% DMSO was used to dissolve CEO and cinnamaldehyde. MIC was measured after $24 \mathrm{~h}$ incubation and each test was conducted in triplicates. In order to evaluate the bactericidal/bacteriostatic effects of these oils, the cultured medium from wells which have no visible bacterial growth was smeared on separate tryptic soy agar (TSA) (MB Cell, LA, CA) plates and incubated for $24 \mathrm{~h}$ at $27^{\circ} \mathrm{C}$. The concentration, at which no growth was observed on TSA plate, was determined as MBC.

Determination of antibiotic sensitivity pattern of the bacterial strains

The antibiogram of the test strains was studied by disk diffusion method using fourteen antibiotics and their multiple antibiotic resistant index (MRI \%) were determined (Magiorakos et al., 2012) in order to compare the antibacterial activity of the oils with standard antibacterial drugs. Resistance profiles were assigned using criteria described by Clinical and Laboratory Standards Institute (CLSI) (CLSI, 2014). The MRI \% was determined following the method described by Das and Rath (2012). Each test was repeated three times.

\section{Statistical analysis}

Comparison between MIC values and IZDs of CEO and cinnamaldehyde was done using SPSS analysis tool (SPSS Inc., USA). Differences were considered significant at $\mathrm{p}<0.05$.

\section{Results and discussion}

The main compounds of CEO belong to two chemical classes: polyphenols and volatile phenols. Among polyphenols, CEO contains mainly vanillic, caffeic, p-Coumaric, safrol and ferulic acid (Muchuweti et al., 2007). Cinnamaldehyde is the most reported volatile substance in CEO, with a content ranging from 50 to $90 \%$ (Gupta et al., 2008; Wong et al., 2014; Kaskatepe et al., 2016 ). CEO used in the present study comprised 54.35\% of cinnamaldehyde together with eugenol $(16.59 \%)$, betaCaryophyllene (6.93\%) and linalool (6.37\%) (Table 1).

According to the disk diffusion test result, CEO inhibited the growth of all test bacteria at all concentrations except 1 and 5\% (V/V) (Table 2). Cinnamaldehyde also inhibited growth of all test bacteria at all tested concentrations except at $1 \%(\mathrm{~V} / \mathrm{V})$. In every tested fish pathogenic bacteria, the IZD increased in proportion to the concentration and the maximum effect was found at 100\% $(\mathrm{V} / \mathrm{V})$ concentration of $\mathrm{CEO}$ and cinnamaldehyde. In 
Table 1. Composition of CEO used in this study

\begin{tabular}{ll}
\hline Compound name & Composition (\%) \\
\hline Cinnamaldehyde & 54.35 \\
Eugenol & 16.59 \\
$\beta$-Caryophyllene & 6.93 \\
Linalool & 6.37 \\
Cinnamylacetate & 6.30 \\
1,8 Cineol+beta-Phellandren & 2.26 \\
Benzylbenzoate & 2.16 \\
$\alpha$-Humulen & 0.48 \\
Eugenylacetate & 0.47 \\
Safrol & 0.42 \\
$\alpha$-Phellandren & 0.40 \\
$\alpha$-Copaen & 0.38 \\
Pracymene & 0.35 \\
Caryophyllenoxide & 0.19 \\
$\alpha$-Pinene & 0.16 \\
Limonene & 0.15 \\
$\alpha$-Terpinol & 0.12 \\
cis-Cinnamaldehyde & 0.10 \\
Zimtalcohol & 0.03 \\
Benzylalcohol & 0.02
\end{tabular}

${ }^{a}$ Composition of the essential oil was analysed by Neumond $\mathrm{GmbH}$, Raisting, Germany comparison, cinnamaldehyde showed higher IZD values than CEO. The IZDs of Gram negative bacteria ranged from 19 to $30 \mathrm{~mm}$ and the IZDs of Gram positive bacteria ranged from 16 to $32 \mathrm{~mm}$ at $100 \%(\mathrm{~V} / \mathrm{V})$ of CEO. The IZD of Gram negative bacteria ranged from 28 to $46 \mathrm{~mm}$ at $100 \%(\mathrm{~V} / \mathrm{V})$ of cinnamaldehyde while the IZD of Gram positive bacteria ranged from 22 to $30 \mathrm{~mm}$ (Table 2). In previous studies, CEO inhibited the growth of Bacillus cereus, Staphylococcus aureus and Pseudomonas aeruginosa with low IZD values than observed in the present study (Gupta et al., 2008). Cinnamaldehyde inhibited the growth of Gram positive bacteria (B. cereus, Enterococcus faecalis. Listeria monocytogenes and $S$. aureus) and Gram negative bacteria ( $P$. aeruginosa, Escherichia coli and Salmonella enteritidis) and the IZDs ranged from 23 to $30 \mathrm{~mm}$ and 12 to $23 \mathrm{~mm}$, respectively (Sanla-Ead et al., 2011). The mode of action of antimicrobial drugs depends on the type of microorganism and studies indicated that essential oils (Eos) are mainly associated with cell membrane damage (Cox et al,. 2001).

The higher RIZD\% was exhibited at higher concentration of CEO and cinnamaldehyde. The highest RIZD \% for CEO was 111 against $P$. damselae (FP4101)

Table 2. Inhibition zone dia (IZD) and the percentage of relative inhibition zone dia (RIZD\%) values of CEO and cinnamaldehyde against fish pathogenic bacteria

\begin{tabular}{|c|c|c|c|c|c|c|c|c|c|c|c|c|c|}
\hline \multirow{3}{*}{ Bacteria } & \multirow{3}{*}{ Agent $^{\text {a }}$} & \multicolumn{12}{|c|}{ Inhibition zone dia $(\mathrm{mm})$ and RIZD \% ${ }^{\mathrm{b}}$} \\
\hline & & \multicolumn{2}{|c|}{$1 \%(\mathrm{~V} / \mathrm{V})$} & \multicolumn{2}{|c|}{$5 \%(\mathrm{~V} / \mathrm{V})$} & \multicolumn{2}{|c|}{$10 \%(\mathrm{~V} / \mathrm{V})$} & \multicolumn{2}{|c|}{$25 \%(\mathrm{~V} / \mathrm{V})$} & \multicolumn{2}{|c|}{$50 \%(\mathrm{~V} / \mathrm{V})$} & \multicolumn{2}{|c|}{$100 \%(\mathrm{~V} / \mathrm{V})$} \\
\hline & & IZD & RIZD & IZD & RIZD & IZD & RIZD & IZD & RIZD & IZD & RIZD & IZD & RIZD \\
\hline \multirow[t]{2}{*}{ V. harveyi (FP8370) } & $\mathrm{C}$ & 0 & 0 & 0 & 0 & 10 & 41.7 & 20 & 83.3 & 23 & 95.8 & 26 & 108 \\
\hline & $\mathrm{CL}$ & 0 & 0 & 9 & 37.5 & 15 & 62.5 & 18 & 75 & 24 & 100 & 28 & 117 \\
\hline \multirow[t]{2}{*}{ V. ichthyoenteri (FP4004) } & $\mathrm{C}$ & 0 & 0 & 0 & 0 & 12 & 31.6 & 16 & 42.1 & 20 & 52.6 & 26 & 68.4 \\
\hline & $\mathrm{CL}$ & 0 & 0 & 10 & 26.3 & 16 & 42.1 & 24 & 63.2 & 28 & 73.7 & 30 & 78.9 \\
\hline \multirow{2}{*}{ P. damselae (FP4101) } & $\mathrm{C}$ & 0 & 0 & 10 & 37 & 11 & 40.7 & 24 & 88.9 & 26 & 96.3 & 30 & 111 \\
\hline & $\mathrm{CL}$ & 0 & 0 & 12 & 44.4 & 15 & 55.6 & 20 & 92.6 & 24 & 88.9 & 32 & 119 \\
\hline \multirow[t]{2}{*}{ E. tarda (FP5060) } & $\mathrm{C}$ & 0 & 0 & 0 & 0 & 12 & 44.4 & 15 & 55.6 & 17 & 63 & 19 & 70.4 \\
\hline & $\mathrm{CL}$ & 0 & 0 & 10 & 37 & 20 & 74.1 & 22 & 81.5 & 26 & 96.3 & 30 & 111 \\
\hline \multirow[t]{2}{*}{ E. tarda (ED47) } & $\mathrm{C}$ & 0 & 0 & 8 & 33.3 & 11 & 45.8 & 15 & 62.5 & 17 & 70.8 & 19 & 79.2 \\
\hline & $\mathrm{CL}$ & 0 & 0 & 11 & 45.8 & 18 & 75 & 24 & 100 & 38 & 158 & 46 & 192 \\
\hline \multirow[t]{2}{*}{ E. tarda (Yoshida) } & $\mathrm{C}$ & 0 & 0 & 8 & 29.6 & 11 & 40.7 & 16 & 59.3 & 26 & 96.3 & 28 & 104 \\
\hline & CL & 0 & 0 & 12 & 44.4 & 16 & 59.3 & 21 & 77.8 & 30 & 111 & 40 & 148 \\
\hline \multirow[t]{2}{*}{ E. tarda (ED45) } & $\mathrm{C}$ & 0 & 0 & 11 & 45.8 & 15 & 62.5 & 17 & 70.8 & 18 & 75 & 20 & 83.3 \\
\hline & $\mathrm{CL}$ & 0 & 0 & 15 & 62.5 & 22 & 91.7 & 30 & 125 & 32 & 133 & 34 & 142 \\
\hline \multirow[t]{2}{*}{ L. garvieae (FP5245) } & $\mathrm{C}$ & 0 & 0 & 0 & 0 & 11 & 44 & 12 & 48 & 14 & 56 & 17 & 68 \\
\hline & $\mathrm{CL}$ & 0 & 0 & 8 & 32 & 11 & 44 & 17 & 68 & 20 & 80 & 22 & 88 \\
\hline \multirow[t]{2}{*}{ S. iniae (FP3287) } & $\mathrm{C}$ & 0 & 0 & 0 & 0 & 10 & 35.7 & 13 & 46.4 & 14 & 50 & 16 & 57.1 \\
\hline & $\mathrm{CL}$ & 0 & 0 & 10 & 36 & 16 & 57.1 & 21 & 75 & 22 & 78.6 & 24 & 85.7 \\
\hline S. iniae (S186) & $\mathrm{C}$ & 0 & 0 & 0 & 0 & 8 & 22.9 & 17 & 48.6 & 19 & 54.3 & 20 & 57.1 \\
\hline
\end{tabular}




\begin{tabular}{llllllllllllll}
\hline & CL & 0 & 0 & 12 & 34.3 & 22 & 62.9 & 24 & 68.6 & 26 & 74.3 & 30 & 85.7 \\
S. iniae (S530) & $\mathrm{C}$ & 0 & 0 & 0 & 0 & 15 & 39.5 & 17 & 44.7 & 20 & 52.6 & 23 & 60.5 \\
\multirow{3}{*}{ S. iniae (S131) } & $\mathrm{CL}$ & 0 & 0 & 10 & 26.3 & 20 & 52.6 & 22 & 57.9 & 28 & 73.7 & 30 & 78.9 \\
& $\mathrm{C}$ & 0 & 0 & 0 & 0 & 14 & 40 & 20 & 57.1 & 26 & 74.3 & 32 & 91.4 \\
S. parauberis (FP5228) & $\mathrm{CL}$ & 0 & 0 & 13 & 37.1 & 22 & 62.9 & 24 & 68.6 & 30 & 85.7 & 34 & 97.1 \\
& $\mathrm{C}$ & 0 & 0 & 0 & 0 & 12 & 42.9 & 17 & 60.7 & 19 & 67.9 & 20 & 71.4 \\
S. parauberis (S124) & $\mathrm{CL}$ & 0 & 0 & 11 & 39.2 & 14 & 50 & 17 & 60.7 & 22 & 78.6 & 26 & 92.9 \\
S. parauberis (S527) & $\mathrm{C}$ & 0 & 0 & 0 & 0 & 10 & 40 & 13 & 52 & 15 & 60 & 17 & 68 \\
& $\mathrm{CL}$ & 0 & 0 & 10 & 40 & 15 & 60 & 16 & 64 & 17 & 68 & 20 & 80 \\
S. parauberis (S1466) & $\mathrm{C}$ & 0 & 0 & 0 & 0 & 12 & 41.4 & 22 & 75.9 & 26 & 89.7 & 26 & 89.7 \\
& $\mathrm{CL}$ & 0 & 0 & 12 & 41.3 & 14 & 48.3 & 16 & 55.2 & 22 & 75.9 & 28 & 82.8 \\
& $\mathrm{C}$ & 0 & 0 & 0 & 0 & 10 & 37 & 14 & 51.9 & 15 & 55.6 & 16 & 59.3 \\
& $\mathrm{CL}$ & 0 & 0 & 13 & 48.1 & 12 & 44.4 & 26 & 96.3 & 28 & 96.6 & 30 & 103 \\
\hline
\end{tabular}

${ }^{\text {a }}$ C- CEO, CL- Cinnamaldehyde

${ }^{\mathrm{b}}$ IZD- Inhibition zone dia, RIZD- Percentage of relative inhibition zone dia

and for cinnamaldehyde it was 192 against $E$. tarda (ED47) (Table 2). It was observed that CEO had zero RIZD \% against all Gram positive strains and three Gram negative strains [(V. harveyi (FP8370), V. ichthyoenteri (FP4004) and E. tarda (FP5060)] at 5\% (V/V) concentration. Gram negative strains exhibited higher RIZD \% than Gram positive strains and there was a significant difference between RIZD \% of Gram negative and Gram positive strains $(\mathrm{p}<0.05)$.

In the present study, a significant difference $(p<0.05)$ was observed between MIC values of Gram positive and Gram negative bacteria. MIC of CEO for bacterial strains ranged from 0.001 to $0.031 \%$ (V/V) (Table 3). Cinnamaldehyde showed lower MIC values than CEO for every strain which ranged from 0.001 to $0.015 \%(\mathrm{~V} / \mathrm{V})$, except six strains. In a previous study, both EO and cinnamaldehyde were equally effective in inhibiting the growth of bacteria (both Gram positive and Gram negative) and the lowest MIC was obtained against $V$. parahaemolyticus while the highest MIC values were obtained against $E$. coli and $P$. aeruginosa (Rattanachaikunsopon and Phumkhachorn, 2010). Plant EOs can be classified into two categories, considering the $\mathrm{MBC} / \mathrm{MIC}$ ratio. EOs which exhibit $\mathrm{MBC} / \mathrm{MIC}$ ratio $\leq 4$ are denoted as bactericidal for tested bacteria, while the EOs which demonstrate MBC/MIC ratio $>4$ are expressed as bacteriostatic (Kone et al. 2004). According to this study, CEO demonstrated only bactericidal activity against the tested pathogenic bacteria, while cinnamaldehyde

Table 3. Susceptibility pattern of CEO and cinnamaldehyde against fish pathogenic bacteria

\begin{tabular}{|c|c|c|c|c|c|c|}
\hline \multirow{2}{*}{ Bacteria } & \multicolumn{2}{|c|}{$\mathrm{CEO}$} & \multirow{2}{*}{$\mathrm{MBC} / \mathrm{MIC}$} & \multicolumn{2}{|c|}{ Cinnamaldehyde } & \multirow{2}{*}{$\mathrm{MBC} / \mathrm{MIC}$} \\
\hline & $\mathrm{MIC} \%(\mathrm{~V} / \mathrm{V})$ & $\mathrm{MBC} \%(\mathrm{~V} / \mathrm{V})$ & & $\mathrm{MIC} \%(\mathrm{~V} / \mathrm{V})$ & $\mathrm{MBC} \%(\mathrm{~V} / \mathrm{V})$ & \\
\hline V. harveyi (FP8370) & 0.007 & 0.031 & 4 & 0.001 & 0.007 & 7 \\
\hline V. ichthyoenteri (FP4004) & 0.007 & 0.031 & 4 & 0.001 & 0.007 & 7 \\
\hline P. damselae (FP4101) & 0.003 & 0.007 & 2 & 0.001 & 0.003 & 3 \\
\hline E. tarda (FP5060) & 0.003 & 0.015 & 4 & 0.003 & 0.003 & 1 \\
\hline E. tarda (ED47) & 0.003 & 0.015 & 4 & 0.001 & 0.003 & 3 \\
\hline E. tarda (Yoshida) & 0.001 & 0.003 & 3 & 0.001 & 0.001 & 1 \\
\hline E. tarda (ED45) & 0.001 & 0.007 & 4 & 0.001 & 0.007 & 7 \\
\hline L. garvieae (FP5245) & 0.015 & 0.031 & 2 & 0.003 & 0.015 & 5 \\
\hline S. iniae (FP3287) & 0.031 & 0.062 & 2 & 0.003 & 0.007 & 2 \\
\hline S. iniae (S186) & 0.015 & 0.031 & 2 & 0.015 & 0.015 & 1 \\
\hline S. iniae (S530) & 0.015 & 0.062 & 4 & 0.007 & 0.031 & 4 \\
\hline S. iniae (S131) & 0.015 & 0.062 & 4 & 0.007 & 0.031 & 4 \\
\hline S. parauberis (FP5228) & 0.015 & 0.031 & 2 & 0.015 & 0.062 & 4 \\
\hline S. parauberis (S124) & 0.007 & 0.031 & 4 & 0.015 & 0.031 & 2 \\
\hline S. parauberis (S527) & 0.007 & 0.015 & 2 & 0.003 & 0.015 & 5 \\
\hline S. parauberis (S1466) & 0.007 & 0.015 & 2 & 0.007 & 0.015 & 2 \\
\hline
\end{tabular}


demonstrated both bactericidal and bacteriostatic activity. Mean MBC/MIC for CEO was 2 to 4 and for cinnamaldehyde it was 1 to 7 (Table 3). Previous studies showed that the effect of CEO and cinnamaldehyde was bactericidal for $S$. aureus and E. coli (Pozzo et al., 2012; Zhang et al., 2016).

The MRI\% of the isolates ranged between 0-57.1. E. tarda (ED45 and ED47) showed the highest MRI\% (57.1), followed by both L. garvieae (FP5245) and S. iniae (FP3287) (35.7) (Table 4). The antibiogram pattern indicated that all the bacterial strains excluding three strains of S. iniae (S186, S530 and S131) showed resistance to one or more antibiotics. S. iniae (S186, S530 and $\mathrm{S} 131$ ) showed the lowest MRI \% which in turn reflects its susceptibility towards the antibiotics. It is important to mention that the degree of inhibition (in terms of zone size) by CEO and cinnamaldehyde was distinct compared to standard antibiotics. In some strains, the zones of inhibition by the antibiotics were smaller than the zones of inhibition represented by CEO and cinnamaldehyde at $100 \%(\mathrm{~V} / \mathrm{V})$ concentration. Antimicrobial activity of CEO and cinnamaldehyde might be due to inhibition of cell membrane synthesis. Previous studies observed impaired membrane structure and swollen cells at higher CEO concentrations. The structural changes in bacterial cells occur due to the lysis of membrane and the changes in the permeability of membrane caused by CEO. Consequently, the changes can lead to loss of inner

Table 4. Antibiogram pattern of the fish pathogenic bacteria

\begin{tabular}{|c|c|c|c|}
\hline \multirow{2}{*}{ Bacteria } & \multicolumn{2}{|c|}{ Antibiotics $^{\mathrm{a}}$} & \multirow{2}{*}{ MRI \% } \\
\hline & Sensitive & Resistant & \\
\hline V. harveyi (FP8370) & $\begin{array}{l}\text { AMX, AMP, CTX, CRO, TCI, CHL, } \\
\text { OFX, IMI, SXT, E, DA }\end{array}$ & VA, NAL, CN & 21.4 \\
\hline V. ichthyoenteri (FP4004) & $\begin{array}{l}\text { AMX, AMP, CTX, CRO, TCI, CHL, } \\
\text { OFX, NAL, CN, IMI, SXT, E, DA }\end{array}$ & VA, & 7.1 \\
\hline P. damselae (FP4101) & $\begin{array}{l}\text { AMX, AMP, CTX, CRO, TCI, CHL, } \\
\text { OFX, NAL, CN, IMI, SXT, E, DA }\end{array}$ & VA, & 7.1 \\
\hline E. tarda (FP5060) & $\begin{array}{l}\text { AMX, CTX, CRO, TCI, CHL, } \\
\text { OFX, NAL, IMI, SXT, E, DA }\end{array}$ & AMP, CN, VAN, & 21.4 \\
\hline E. tarda (ED47) & AMX, CTX, CRO, IMI, E, DA & $\begin{array}{l}\text { AMP, TCI, CHL, VA, NAL } \\
\text { SXT, OFX,CN }\end{array}$ & 57.1 \\
\hline E. tarda (Yoshida) & $\begin{array}{l}\text { AMX, AMP, CTX, CRO,TCI, CHL, } \\
\text { OFX, NAL, CN, IMI, SXT, E, DA, }\end{array}$ & VA, & 7.1 \\
\hline E. tarda (ED45) & AMX, CTX, CRO, IMI, E, DA & $\begin{array}{l}\text { AMP,TC,CHL, VA, NAL, } \\
\text { SXT, OFX, CN }\end{array}$ & 57.1 \\
\hline L. garvieae (FP5245) & $\begin{array}{l}\text { AMX, TC, DA, E, VA, NAL, CN } \\
\text { IMI, SXT }\end{array}$ & AMP, CTX, CRO, CHL OFX & 35.7 \\
\hline S. iniae (FP3287) & $\begin{array}{l}\text { AMX, TC, CHL, E, VA, NAL, CN } \\
\text { IMI, SXT }\end{array}$ & AMP, CTX, CRO, DA, OFX & 35.7 \\
\hline S. iniae (S186) & $\begin{array}{l}\text { AMX, AMP, CTX, CRO, TC, CHL } \\
\text { E, DA, VA, OFX, NAL, CN, IMI, SXT }\end{array}$ & - & 0 \\
\hline S. iniae (S530) & $\begin{array}{l}\text { AMX, AMP, CTX, CRO, TC, CHL } \\
\text { E, DA, VA, OFX, NAL, CN, IMI,SXT }\end{array}$ & - & 0 \\
\hline S. iniae (S131) & $\begin{array}{l}\text { AMX, AMP, CTX, CRO, TC, CHL, E } \\
\text { DA, VA,OFX, NAL,CN, IMI, SXT }\end{array}$ & - & 0 \\
\hline S. parauberis (FP5228) & $\begin{array}{l}\text { AMX, CTX, CRO, TC E DA VA } \\
\text { OFX, NAL, CN, IMI, SXT }\end{array}$ & AMP, CHL & 14.3 \\
\hline S. parauberis (S124) & $\begin{array}{l}\text { AMX, CTX, CRO, VA, CHL, OFX } \\
\text { NAL, CN, IMI, SXT }\end{array}$ & AMP, TC, E, DA & 28.6 \\
\hline S. parauberis (S527) & $\begin{array}{l}\text { AMX, CTX, CRO, TC, CHL, SXT } \\
\text { E, DA, VA, OFX, NAL, CN, IMI }\end{array}$ & AMP & 7.1 \\
\hline S. parauberis (S1466) & $\begin{array}{l}\text { AMX,CTX, CRO, TC, CHL, NAL } \\
\text { DA, VA, OFX, CN, IMI, SXT }\end{array}$ & AMP, E & 14.3 \\
\hline
\end{tabular}


E15-Erythromycin $(15 \mu \mathrm{g})$, DA10-Clindamycin $(10 \mu \mathrm{g})$, VA30-Vancomycin $(30 \mu \mathrm{g})$, OFX5-Ofloxacin $(5 \mu \mathrm{g})$, NAL30-Nalidixic acid (30 $\mu \mathrm{g})$, CN10Gentamicin $(10 \mu \mathrm{g})$, IMI10-Imipenem (10 $\mu \mathrm{g})$, SXT25- Trimethoprim-sulfamethoxazole (25 $\mu \mathrm{g})$, AMX30-Amoxicillin $(30 \mu \mathrm{g})$ 
cell materials (Shin et al., 2007; Bajpai et al., 2013). Cinnamaldehyde damages and destroys the bacterial cell surface and interfere in biological processes of bacteria by altering electron transfer and reacting with nitrogencontaining components such as proteins and nucleic acids. Furthermore, cinnamaldehyde inhibits amino acid decarboxylase activity and decrease cellular glutathione levels (Haines and Shankel, 1990; Gupta et al., 2008).

In the present study, CEO and cinnamaldehyde inhibited the growth of tested fish pathogenic bacteria isolated from olive flounder. The findings of the present study highlight the promising role of CEO and cinnamaldehyde as good candidates for further research to develop a new alternative antibacterial drug against fish pathogenic bacteria. They can be used to prevent or treat fish diseases by adding to fish feed or by immersion treatment. Studies about pharmacokinetics of CEO and cinnamaldehyde and in vivo effects suggested that they may not pose a risk for fish health (Rattanachaikunsopon and Phumkhachorn, 2010). Therefore, in order to apply CEO and cinnamaldehyde for treatment of bacterial diseases in aquaculture, their stability in the aquatic environment, palatability and absorption rate in fish need to be further investigated.

\section{Acknowledgements}

Authors are thankful to Professor Tae-Sung Jung of Institute of Animal Medicine, College of Veterinary Medicine, Gyeongsang National University, Jinju, Korea and National Institute of Fisheries Science, Busan, Korea for providing the bacterial strains used in this study.

\section{References}

Bajpai, V. K., Sharma, A. and Baek, K. H. 2013. Antibacterial mode of action of Cudrania tricuspidata fruit essential oil, affecting membrane permeability and surface characteristics of food-borne pathogens. Food Control, 32: $582 \mathrm{e}-590$

Burt, S. 2004. Essential oils: their antibacterial properties and potential applications in foods-a review. Int. J. Food Microbiol., 94: 223-253.

CLSI 2014. Performance standards for antimicrobial susceptibility testing of bacteria isolated from aquatic animals; second informational supplement. CLSI document VET03/VET04-S2. Clinical and Laboratory Standards Institute, Wayne, PA, USA..

Cox, S. D., Mann, C. M. and Markham, J. L. 2001. Interactions between components of the essential oil of Melaleuca alternifolia. J. Appl. Microbiol., 91: 492-497.

Das, M. and Rath, C. C. 2012. Bacteriology of a most popular street food (Panipuri) and inhibitory effect of essential oils on bacterial growth. J. Food Sci, Technol., 49(5): 564-571. https://dx.doi.org/10.1007\%2Fs13197-010-0202-2.
Gupta, C., Garg, A. P., Uniyal, R. C. and Kumari, A. 2008. Comparative analysis of the antimicrobial activity of cinnamon oil and cinnamon extract on some food-borne microbes. Afr. J. Microbiol. Res., 2(9): 247-251.

Haines, C. E. and Shankel, D. M. 1990. The effects of cinnamaldehyde and vanillin in growth assays of Escherichia coli and Salmonella typhimurium. Environ. Mol. Mutagen., 15: 23-24.

Hammer, K. A., Carson, C. F. and Riley, T. V. 1999. Antimicrobial activity of essential oils and other plant extracts. J. Appl. Microbiol., 86: 985-90.

Jee, B.Y., Shin, K.W., Lee, D.W., Kim, Y. J. and Lee, M. K., 2014. Monitoring of the mortalities and medications in the inland farms of olive flounder Paralichthys olivaceus, in South Korea. J. Fish Pathol., 27(1): 77-83. https://doi. org/10.7847/jfp.2014.27.1.077.

Kaskatepe, V., Kiymaci, M. E., Simsek, D., Erol, H. B. and Erdem, S. A. 2016. Comparison of the contents and antimicrobial activities of commercial and natural cinnamon oils. Indian J. Pharm. Sci., 78(4): 541-548. DOI: 10.4172 /pharmaceutical-sciences. 1000150 .

Kim, S. M., Jun, L. J., Park, M. A., Jung, S. H., Hyun, D. J. and Jeong, J. B. 2015. Monitoring of emaciation disease in cultured olive flounder in Jeju (2010-2013), Korea. Korean J. Fish Aquat. Sci., 48: 719-724.

Kone, W. M., Atindehou, K. K., Terreaux, C., Hostettmann, K., Traore, D. and Dosso, M. 2004. Traditional medicine in north cote-d'ivoire: screening of 50 medicinal plants for antibacterial activity. J. Ethnopharmacol., 93(1): 43-49. DOI: $10.1016 /$ j.jep.2004.03.006.

Magiorakos, A. P., Srinivasan, A., Carey, R. B., Carmeli, Y., Falagas, M. E., Giske, C. G., Harbarth, S., Hindler, J. F., Kahlmeter, G., Olsson-Liljequist, B., Paterson, D. L., Rice, L. B., Stelling, J., Struelens, M. J., Vatopoulos, A., Weber, J. T. and Monnet, D. L. 2012. Multidrug-resistant, extensively drug-resistant and pandrug-resistant bacteria: an international expert proposal for interim standard definitions for acquired resistance. Clin. Microbiol. Infect., 18: $268-281$

Mok, J. S., Song, K. I., Choi, J. N. and Yang, H. S. 2001. Antibacterial effect of cinnamon (Cinnamomum cassia) bark extract against fish pathogenic bacteria. J. Korean Fish Soc., 34: 545-549.

Muchuweti, M., Kativu, E., Mupure, C. H., Chidewe, C., Ndhlala, A. R. and Benhura, M. A. N. 2007. Phenolic composition and antioxidant properties of some spices. American J. Food Technol., 2(5): 414-420. DOI: 10.3923/ ajft.2007.414.420.

Nazzaro, F., Fratianni, F., Martino, L. D., Coppola, R. and Feo, V. D. 2013. Effect of essential oils on pathogenic bacteria. Pharm., 6(12): 1451-1474. doi: 10.3390/ph6121451.

Nho, S. W., Shin, G. W., Park, S. B., Jang, H. B., Cha, I. C., Ha. M. A., Kim, Y. R., Park, Y. K., Dalvi, R. S., Kang, B. J., 
Joh, S. J. and Jung, T. S. 2009. Phenotypic characteristics of Streptococcus iniae and Streptococcus parauberis isolated from olive flounder (Paralichthys olivaceus). FEMS Microbiol. Lett., 293(1): 20-7. doi: 10.1111/j.15746968.2009.01491.x.

Njau, E. A, Alcorn, J., Ndakidemi, P., Chirino-Trejo, N. and Buza, J. 2014. Antimicrobial and antioxidant activity of crude extracts of Rauvolfia caffra var. caffra (Apocynaceae) from Tanzania. Int. J. Biol., 6(4): 156-167. doi:10.5539/ijb. v6n4p156.

Pongsak, R. and Parichat, P. 2009. Protective effect of clove oil-supplemented fish diets on experimental Lactococcus garvieae infection in tilapia. Biosci. Biotechnol. Biochem., 73(9): 2085-2089. https://doi.org/10.1271/bbb.90294.

Pozzo, M. D., Loreto, E. S., Santurio, D. F., Alves, S. H., Rossatto, L., De Vargas, A. C., Viegas, J. and Costa, M. M. D. 2012. Antibacterial activity of essential oil of cinnamon and trans-cinnamaldehyde against Staphylococcus spp. isolated from clinical mastitis of cattle and goats. Acta Scientiae Veterinariae, 40: 1-5.

Prabuseenivasan, S., Jayakumar, M. and Ignacimuthu, S. 2006. In vitro antibacterial activity of some plant essential oils. BMC Complement Alt. Med., 6: 39. doi: 10.1186/1472-68 82-6-39.

Raeisi, M., Tajik, H., Yarahmadi, A. and Sanginabadi, S. 2015. Antimicrobial effect of cinnamon essential oil against Escherichia coli and Staphylococcus aureus. Health Scope, 4: e21808. doi: 10.17795.

Rattanachaikunsopon, P. and Phumkhachorn, P. 2010. Potential of cinnamon (Cinnamomum verum) oil to control Streptococcus iniae infection in tilapia (Oreochromis niloticus). Fish Sci., 76(2): 287-293. DOI: 10.1007/s12 562-010-0218-6.

Sanla-Ead, N., Jangchud, A., Chonhenchob, V. and Suppakul, P. 2011. Antimicrobial activity of cinnamaldehyde and eugenol and their activity after incorporation into cellulosebased packaging films. Packaging Technol. Sci., 25: 7-17.
Shin, S.Y., Bajpai, V. K., Kim, H. R. and Kang, S. C. 2007. Antibacterial activity of bio converted eicosapentaenoic (EPA) and docosahexaenoic acid (DHA) against foodborne pathogenic bacteria. Int. J. Food Microbiol., 113(2): 233e236. DOI:10.1016/j.ijfoodmicro.2006.05.020.

Turker, H. and Yildirim, A. B. 2015. Screening for antibacterial activity of some Turkish plants against fish pathogens: a possible alternative in the treatment of bacterial infections. Biotechnol. Biotechnol. Equip., 29(2): 281-288. DOI: 10.1080/13102818.2015.1006445.

Valladao, G. M. R., Gallani, S. U. and Pilarski, F. 2015. Phytotherapy as an alternative for treating fish disease. J. Vet. Pharmacol. Therap., 38(5): 417-428. doi: 10.1111/ jvp.12202.

Wei, L. S. and Wee, W. 2013. Chemical composition and antimicrobial activity of Cymbopogon nardus (citronella) essential oil against systemic bacteria of aquatic animals. Iranian J. Microbiol., 5(2):147-152.

Wong, Y. C., Ahmad, M. M. Y. and Wan, N.W. A. 2014. Extraction of essential oil from cinnamon (Cinnamomum zeylanicum). Orient J. Chem., 30(1): 37-47. DOI : http:// dx.doi.org/10.13005/ojc/300105.

Yuce, A., Turk, G., Ceribas, S., Sonmez, M., Ciftc, M. and Guvenc, M. 2012. Effects of cinnamon (Cinnamomum zeylanicum) bark oil on testicular antioxidant values, apoptotic germ cell and sperm quality. First Int. J. Androlo., 45: 248-255.

Zhang, Y., Liu, X., Wang, Y., Jiang, P. and Quek, S.Y. 2016. Antibacterial activity and mechanism of cinnamon essential oil against Escherichia coli and Staphylococcus aureus. Food Control, 59: 282-289.

Zouheyr, H., Rachida, A. and Perry, M. G. 2014. Effect of essential oil of Cinnamomum zeylanicum on some pathogenic bacteria. Afr. J. Microbiol. Res., 8(10): 1026-1031. DOI: 10.5897/AJMR2013.6519. 